\title{
PRELIMINARY REPORT OF HIV AND Toxoplasma gondii OCCURRENCE IN PREGNANT WOMEN FROM MOZAMBIQUE
}

\begin{abstract}
SUMMARY
Toxoplasmosis, a protozoan disease, causes severe disease in fetuses during pregnancy and deadly encephalitis in HIV patients. There are several studies on its seroprevalence around the world, but studies focusing on African countries are limited in number and mostly anecdotal. We studied two groups of samples from Mozambique by ELISA, using serum samples from 150 pregnant women and six Cerebrospinal fluid (CSF) samples from AIDS patients with encephalitis. HIV status was confirmed, and CD4 blood counts were obtained from HIV-positive pregnant women. IgG seroprevalence of the group as a whole was $18.7 \%$ (28/150), with a higher prevalence in HIV-positive individuals compared to those who were HIV-negative (31.3\%, [18/58] vs. 10.9\%, [10/92]) patients. These data may be biased due to cumulative effects of exposition affecting disease prevalence. If corrected, this data may indicate an interaction of HIV and T. gondii. Prevalence of both diseases increases with age, but this is more clearly seen for toxoplasmosis $(\mathrm{p}<0.005)$ than HIV infection, possibly explained by higher transmission of HIV after childhood. In HIV patients suffering from encephalitis, CSF serology showed that 33\% of specific IgG CSF had a high avidity, which was in accordance with the data from the group of pregnant women. Lower prevalence rates of both infections in older groups could be explained by more deaths in the infected groups, resulting in an artificially lower prevalence. Using CD4 counts as a marker of time of HIV infection, and correcting for age, patients with contact with T. gondii had fewer CD4 cells, suggesting prolonged HIV disease or other causes. Toxoplasma IgG prevalence is higher in HIV+ groups, which could be ascribed to HIV- and T. gondii-associated risk factors, such as exposure to higher and more diverse social contacts. The low incidence of Toxoplasma $\mathrm{IgG}$ in younger age groups shows that transmission could be related to better access to cyst-containing meat in adulthood, as environmental transmission due to oocysts is usually blamed for higher incidence in children. Taken together, these data support the urgent need of research in toxoplasmosis in Africa, especially in the presence of HIV epidemics.
\end{abstract}

KEYWORDS: Austral Africa; Toxoplasmosis; HIV; Serology; Pregnant women.

\section{INTRODUCTION}

Toxoplasma gondii infection occurs worldwide, and it is one of the most common infections in humans. The infection is mainly acquired by ingestion of undercooked or raw meat containing viable tissue cysts, or by ingestion of food and water that is contaminated with oocysts shed by felids (DUBEY \& JONES, 2008). Although the course of the primary infection is usually subclinical and the vast majority of the infected human population remains asymptomatic, the infection can cause significant morbidity and mortality in certain groups (WEISS \& DUBEY, 2009). Toxoplasmosis can cause severe disease in fetuses of acutely infected pregnant women (MONTOYA \& REMINGTON, 2008). Additionally, the reactivation of latent infection occurs in immune compromised patients, causing life-threatening disease, especially encephalitis (PASSOS et al., 2000). Encephalitis due to reactivated toxoplasmosis is one of the most common opportunistic neurological infections in AIDS patients, typically observed in the later stages of human immunodeficiency virus (HIV) infection (MASCHKE et al., 2000). Its incidence is directly related to the prevalence of anti-T. gondii antibodies in the general population (PASSOS et al., 2000). The prevalence of toxoplasmosis (between $30 \%$ and $60 \%$ in most countries) varies widely in different regions of the globe (TENTER et al., 2000). Few studies on this prevalence have been conducted in subSaharan Africa (SHIMELIS et al., 2009, LINDSTRON et al., 2006) or in Austral Africa. Instead, studies have mostly been conducted in South Africa (HARI et al., 2007), where the disease was first described in the 1950s (BECKER, 1954; FASSER, 1955).

In Mozambique, physicians anecdotally report congenital toxoplasmosis or AIDS encephalitis, but the true occurrence of toxoplasmosis, which is currently estimated by anti- $T$. gondii antibodies in pregnant women and patients with HIV/AIDS is unknown. We believe that defining the occurrence of toxoplasmosis, using anti-T.gondii 
SITOE, S.P.B.L.; RAFAEL, B.; MEIRELES, L.R.; ANDRADE Jr., H.F. \& THOMPSON, R. - Preliminary report of HIV and Toxoplasma gondii occurrence in pregnant women from Mozambique. Rev. Inst. Med. Trop. Sao Paulo, 52(6): 291-5, 2010.

antibodies during antenatal care in pregnant women or in AIDS patients in our community, would reduce the risk of treatable damage to the CNS and the high morbidity of this type of patient (MASCHKE et al., 2000).

The objective of this study was to determine the occurrence of toxoplasmosis in samples from public health system hospitals and clinics from the Maputo area, by detecting T. gondii-specific IgG antibodies from women in the first trimester of their pregnancy, and also by titering these antibodies and their avidity in Cerebrospinal fluid (CSF) samples from AIDS patients with suspected encephalitis.

\section{MATERIALS AND METHODS}

Samples: We studied 150 serum samples from pregnant women seeking first trimester prenatal care. Serum samples were also tested for HIV infection, and CD4 counts were determined in positive samples. CSF from HIV-positive patients with suspected encephalitis from Hospital Central de Maputo, the large public health facility, were available for confirming Toxoplasma encephalitis using specific antibody detection and avidity assays. This study was performed with approval of the Ethics Commission of HCM and INS and informed consent was obtained from patients or their relatives before collection. All samples were immediately processed and stored at $-20{ }^{\circ} \mathrm{C}$ until use.

Enzyme Linked Immunosorbent Assay (ELISA): Serum samples were examined by immunoenzymatic assay (ELISA) using the commercial kits Toxoplasma gondii IgG ELISA (TOXG-013) and Toxoplasma gondii IgM $\mu$-capture ELISA (T0XM-016) (ELISA-IBL Imuno-Biological Laboratories ${ }^{\circledR}$, Hamburg, Germany) to identify the presence of immunoglobulin $\operatorname{IgG}$ and $\operatorname{IgM}$, according to the manufacturer's instructions.

Cerebrospinal Fluid (CSF) IgG Avidity: The IgG avidity assay was performed as elsewhere described (MEIRELES et al., 2004) with minor modifications. ELISA microplates (Multiwell plate/polystyrene, Sigma) were coated with $100 \mu \mathrm{L} /$ well of a solution containing $10 \mu \mathrm{g} / \mathrm{mL}$ of the $T$. gondii antigen extract diluted in $6 \mathrm{M}$ urea $\mathrm{pH} 7.0$, incubated overnight at $4{ }^{\circ} \mathrm{C}$ and blocked for one hour at $37^{\circ} \mathrm{C}$ with $2 \%$ fat free dry milk. Undiluted CSF was applied to two wells and incubated for one hour at $37^{\circ} \mathrm{C}$. After this, one well was washed with $100 \mu \mathrm{L}$ of $6 \mathrm{M}$ urea $\mathrm{pH} 7.0$, and incubated at $37{ }^{\circ} \mathrm{C}$ for $10 \mathrm{~min}$. After the incubation, bound $\mathrm{IgG}$ was revealed by specific peroxidase conjugate and $o$-phenylenediamine. The $\mathrm{A}_{492 \mathrm{~nm}}$ was determined in the control and urea treated wells by spectrophotometry (Multiskan MS). The avidity of each sample was calculated as the percent of $\mathrm{A}_{492 \mathrm{~nm}}$ resistant to urea. Samples with more than $75 \% \mathrm{~A}_{492 \mathrm{~nm}}$ resistance to urea treatment were considered to have high avidity. Samples with control well values greater than the mean plus three $\mathrm{SD}$ of $\mathrm{A}_{492 \mathrm{~nm}}$ of negative wells were considered positive for $T$. gondii $\mathrm{IgG}$ and toxoplasmosis.

Statistics: Comparisons of frequencies of events between groups were performed using two-tailed Chi-square tests. Comparisons of quantitative data, such as CD4+ counts, were performed using Student's t-tests. Age evolution was tested using linear regression and goodness to fit or $\mathrm{r}^{2}$, with confidence interval comparison between slopes and intercepts. Differences were considered significant when the probability of equality was less than $0.05(\mathrm{p}<0.05)$. We used for all calculations the statistical software Graph Pad Prism 5.0 (GraphPad Software, San Diego California USA, www.graphpad.com).

\section{RESULTS}

We studied two groups of samples using ELISA methods. The populations studied included serum samples from 150 pregnant women from public prenatal care clinics and 6 CSF samples from AIDS patients with encephalitis from the "Hospital Central de Maputo". HIV status was confirmed by serology, and CD4 blood counts were obtained for HIV-positive pregnant women. The age of the subjects ranged from 15 to 50 years old, with an average of 32 years.

The overall occurrence of anti-Toxoplasma $\mathrm{IgG}$ antibodies, as shown in Fig. 1, was $18.7 \%$ (28/150) with only one case $(3.6 \%$, 95\% C.I. 0.09-16) associated with anti- T. gondii IgM antibodies. Toxoplasmosis occurrence was more prevalent in HIV-positive patients $(31.3 \%, 18 / 58)$, when compared to HIV-negative patients $(10.9 \%, 10 / 92)(\mathrm{p}<0.005)$, with a 3.6 Odds Ratio for Toxoplasma infection in HIV-infected individuals. In samples from HIV patients with encephalitis, cerebrospinal fluid serology showed a $33 \%$ (95\% CI 4-77\%) occurrence of specific anti-T. gondii $\mathrm{IgG}$ of high avidity in CSF, which was expected according to the occurrence in this group, and based on our data from the pregnant women.

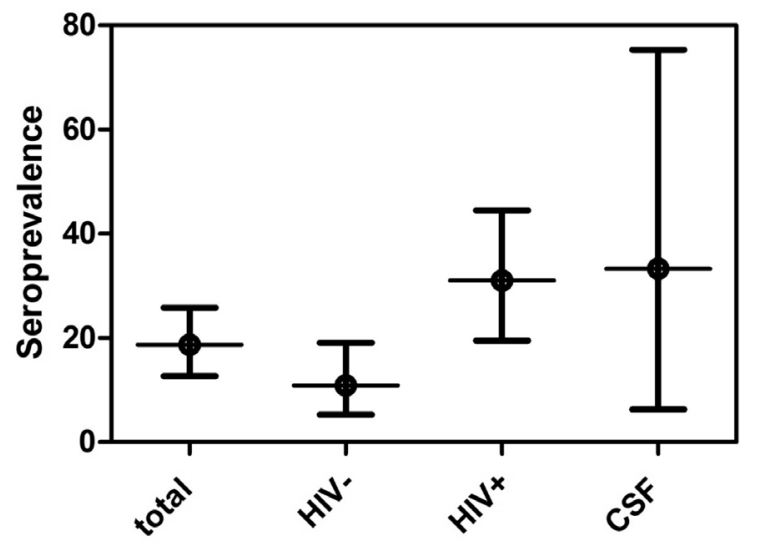

Fig. 1 - Proportion of Toxoplasma-specific antibody detection in sera from pregnant women in Mozambique, in total and sorted according to HIV status, and CSF from encephalitis AIDS patients. Bars represent $95 \%$ confidence interval. In HIV infected women, the odds ratio for toxoplasma infection is 3.6 times higher.

The occurrence of both HIV or Toxoplasma infections increases with age, as shown in Fig. 2, but this is more clearly seen in toxoplasmosis $(\mathrm{p}<0.005)$ than in HIV infection $(\mathrm{p}<0.05)$, with similar slopes, but different intercepts.

Looking for interaction between both infections, we sorted the patients according to HIV status to look for occurrence of Toxoplasmaspecific antibody, or according to occurrence of Toxoplasma specific antibody and frequency of HIV infection in age groups, as shown in Fig. 3. There was a clear increase of Toxoplasma occurrence according to age groups in both HIV-negative (Fig. 3A) and HIV-positive groups (Fig. 3B), but the curves were quite diverse, due to a difference in age of first contact with the agent. The difference in intercepts was significant ( $\mathrm{p}$ $<0.004$ ), without a difference in their slopes. Thus, HIV-infected pregnant women appeared to have had contact with $T$. gondii at lower ages than non-infected women, with a difference of almost 13 years, but after this, the increase of occurrence with age was similar for both groups. After sorting by occurrence of Toxoplasma-specific antibody, the occurrence 


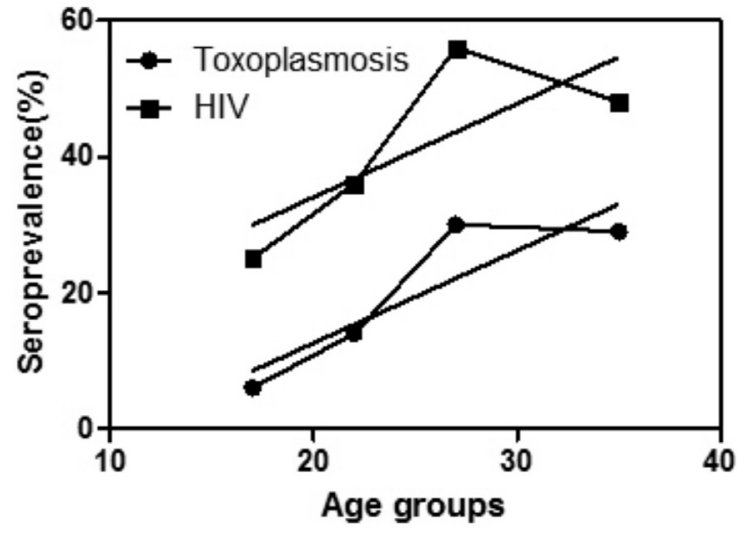

Fig. 2 - Proportion of HIV- and Toxoplasma-specific antibody detection in sera from pregnant women from Mozambique, in total and sorted according to age group.

of HIV infection clearly increased with age in pregnant women without Toxoplasma antibodies (Fig. 3C), but this was not observed in pregnant women with $T$. gondii antibodies, who presented with a higher frequency of HIV infection despite its age group (Fig. 3D).

HIV evolution, as measured by CD4+ cell counts, was evident in the data shown in Fig. 4. The progression of HIV disease, as indicated by low CD4 mean counts, appears to be more intense in Toxoplasma infected patients. This fact is not associated with the age effect or with delayed HIV disease in Toxoplasma-free persons, as it was clearly seen in younger age groups $(<30$ years old $)$, whereas older people did not show the same T. gondii infection effect in their CD4+ cell counts.

\section{DISCUSSION}

Our data concerning the frequency of anti-T. gondii antibodies was similar to other findings in Africa, and suffered from the same problems of sampling populations as similar reports (ZUMLA et al., 1991, LINDSTRON et al., 2006, NABIAS et al., 1998). The planning of an adequate and reliable search for toxoplasmosis is urgently needed in Africa, due to the HIV epidemic and the risk of severe lethal or disabling opportunistic Toxoplasma encephalitis (MAKUWA et al., 1999).

We studied a relatively uniform population, without age differences and of the same ethnicity. The occurrence of both diseases increased with subject age, which is expected with constant exposure. This fact could be explained by a higher transmission of HIV during adulthood in our sample population. Stable or slightly lower occurrences of both infections in older groups could be explained by biased selection of non-infected survivors (resulting from death of infected patients), a defect of cross-sectional studies and the prevalence of HIV infection. HIV occurrence was higher than toxoplasmosis in our population, but
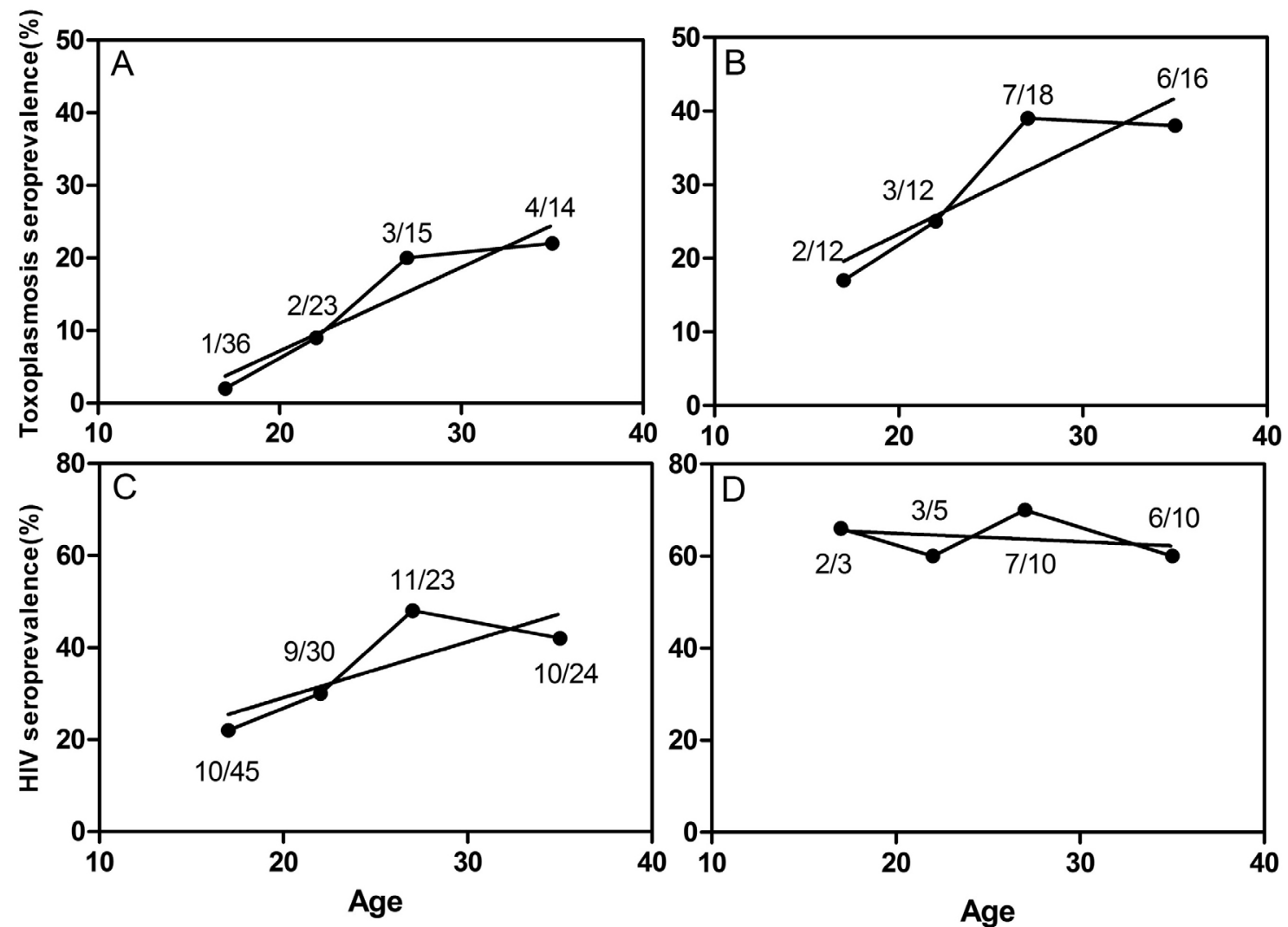

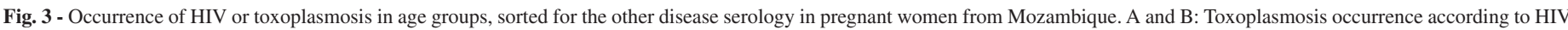

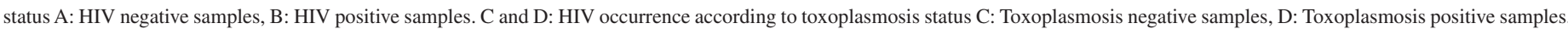
Regression was estimated as continuous lines and numbers are expressed as positive/total in each point. 
SITOE, S.P.B.L.; RAFAEL, B.; MEIRELES, L.R.; ANDRADE Jr., H.F. \& THOMPSON, R. - Preliminary report of HIV and Toxoplasma gondii occurrence in pregnant women from Mozambique. Rev. Inst. Med. Trop. Sao Paulo, 52(6): 291-5, 2010.

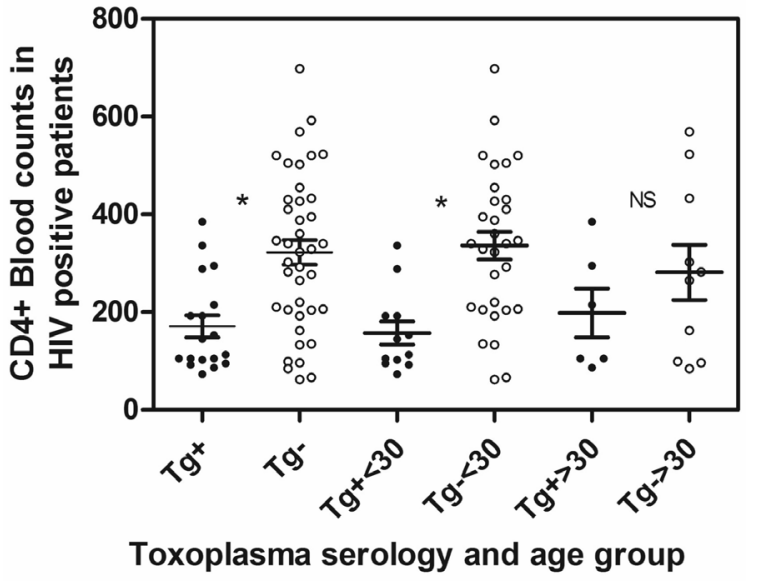

Fig. 4 - Blood CD4+ cells counts in HIV-pregnant women from Mozambique Maputo, according to toxoplasmosis serology and age groups. Open symbols = Toxoplasma negative Closed symbols = Toxoplasma positive. Significant differences are marked as $(*)$ and its absence as (NS). Bars represent mean values and SEM.

toxoplasmosis occurrence was higher in the HIV-infected population, suggesting an interaction between diseases. These data could be biased according to the cumulative effect of deaths due to HIV that similarly could affect occurrence measure. This association of toxoplasmosis and HIV was seen elsewhere in Africa (ZUMLA et al., 1991), but there are few studies of the non-HIV-infected population (SHIMELIS et al., 2009, LINDSTRON et al., 2006). We found a higher toxoplasmosis occurrence in the HIV-positive groups as compared to HIV-negative pregnant women that could be ascribed to common or associated risk factors for both infections, such as exposure to both sexual contacts and meat consumption. This fact is also shown in anti-T.gondii IgG frequency by age group, with a delay of toxoplasmosis risk in older groups of the HIV-negative population, which suggests that the transmission could be related to reduced exposure to cyst-containing meat in adult life, and not an environmental transmission due to oocysts (which is usually associated with a higher incidence in children) (BAHIA-OLIVEIRA et al., 2003). Several explanations for the interaction between both infections resulting in high Toxoplasma infection in HIV patients have been previously proposed (LIN \& BOWMAN, 1992). One possibility is an increase in risky behavior in Toxoplasma infected individuals that leads to increased exposure to HIV infection. Such a change in behavior could be due to parasite-driven personality changes, as described in Toxoplasma-infected individuals in the Czech Republic (FLEGR et al., 1996). Another plausible explanation is that Toxoplasma infection is a marker of exposure to risky social contacts or habits, which correlates with early HIV infection. The access to infected meat would be only a marker of migration from small isolated villages to bigger cities or the improvement of quality of life by better income, resulting in more social contacts, which could also be associated with HIV infection.

The lower CD4 counts found in HIV patients who also presented with anti-T. gondii antibodies, as compared to HIV patients without those antibodies, suggests intense HIV disease progression in this group. Progression could be caused by HIV infection of more CD4 cells with higher viral loads and progressive disease in $T$. gondii chronically infected patients. Toxoplasma infection can promote an increase in CD4 cells by a strong specific immune response (DENKERS \& BUTCHER,
2005), or nonspecific CD4 cell proliferation induced by toxoplasmosis (PURNER et al., 1998). Malaria has similar effects in HIV patients with more severe infections, especially in infants and pregnant women. There is evidence that HIV progression could be more rapid in malaria patients, due to increases in transient viral load in malarial bouts (REITHINGER et al., 2009).

Management of HIV epidemics has been established in industrialized countries without frequent transmissible diseases, but must be reevaluated in Africa, where hyperendemic diseases such as malaria increase the complexity of host disease interactions that alter the immune system's control strategies for all diseases (STILLWAGGON, 2009). Data obtained elsewhere may not apply to areas with other hyperendemic diseases that enhance HIV transmission or disease progression. Our preliminary data includes toxoplasmosis in those diseases. This perverse circuit of meat that can transmit Toxoplasma, thereby increasing the severity of HIV, and with malaria, resulting in longer life with higher viral loads and more transmission, increases the burden of HIV in Africa. Our data suggests that Toxoplasma infection could also affect HIV evolution, either by increasing the risk of rapid evolution of HIV infection or as an opportunistic infection, with disabling or lethal encephalitis.

This data supports the urgent need of research in toxoplasmosis in Africa, especially in the presence of HIV epidemics. The occurrence and peculiarities of toxoplasmosis in Mozambique revealed by this study emphasize the importance of increasing public awareness about the infection in Mozambique. Further studies of toxoplasmosis, in either Maputo or other areas of Mozambique, such as Chokwé and Cape Delgado, are needed to improve our knowledge on the risk of congenital toxoplasmosis and Toxoplasma encephalitis in HIV/AIDS patients. A program for serodiagnosis and prevention of toxoplasmosis in pregnant women or HIV-positive patients could reduce the burden and disabilities in Toxoplasma infections in Mozambique.

\section{RESUMO}

\section{Descrição preliminar da ocorrência de infecção pelo HIV e toxoplasmose em mulheres grávidas em Moçambique}

Toxoplasmose, uma protozoonose, causa doença grave em fetos de mulheres grávidas com infecção aguda e encefalite letal em portadores de HIV. Apesar de muitos estudos sobre sua prevalência no Mundo, existem apenas alguns relatos da toxoplasmose na África Austral, geralmente anedóticos. Estudamos por ELISA dois grupos de amostras de Moçambique, usando 150 amostras de soros de mulheres grávidas e seis amostras de Liquido Cefalorraquidiano (LCR) de pacientes com AIDS e encefalite. $\mathrm{O}$ estado da infecção pelo HIV foi confirmado e a contagem de células CD4+ no sangue foi obtida das pacientes grávidas infectadas pelo HIV. No grupo das gestantes, IgG anti T.gondii foi encontrada em $18.7 \%(28 / 150)$, mais freqüente em pacientes HIV positivas $(31.3 \%$, $18 / 58)$ do que em HIV negativas $(10.9 \%, 10 / 92)$. A ocorrência de ambas as doenças aumenta com a idade, mais claramente vista na toxoplasmose $(\mathrm{p}<0.005)$ do que na infecção pelo HIV, devido maior transmissão do HIV após a infância. Na encefalite em pacientes HIV+, a sorologia do LCR mostrou uma ocorrência de $33 \%$ de IgG especifica de alta avidez, que está de acordo com a ocorrência neste grupo etário, baseado nos dados de nossas gestantes. A menor ocorrência de ambas as infecções em grupos etários mais idosos pode ser explicada pela mortalidade cumulativa por 
qualquer causa nos grupos mais idosos, resultando em menor ocorrência relativa. Usando as contagens de células CD4+ como marcadores da progressão da infecção pelo HIV e corrigindo para grupos etários, as gestantes HIV+ com contato com $T$. gondii tem menores níveis de células CD4+ do que as gestantes HIV+ sem contato com T.gondii. A ocorrência maior da toxoplasmose em gestantes HIV+ pode ser atribuída a fatores de risco semelhantes, como exposição a maior contato social. A baixa ocorrência da toxoplasmose em grupos mais jovens pode se relacionar com menor acesso a carne contendo cistos, já que a transmissão ambiental por oocistos está associada à maior incidência em crianças. Todos estes dados reforçam a necessidade de pesquisa da toxoplasmose na África Austral, especialmente na presença da epidemia pelo HIV.

\section{ACKNOWLEDGEMENTS}

This work was supported by Instituto Nacional de Saúde - Ministério da Saúde-Mozambique, LIMHCFMUSP and CNPq Pró Africa (Proc. No 490374/2008-5). This work is submitted on behalf of S. Sitoe, B. Rafael and R. Thompson, as contact with Maputo authors become very difficult after August 2009. The corresponding author was responsible for the analysis and the submission of the article, in consideration that this work was communicated as an abstract at the $13^{\text {th }}$ International Congress of Protistology, 2009, Búzios, and it was necessary to communicate the data in a published paper in a timely fashion. All contacted authors were in agreement with this arrangement.

\section{REFERENCES}

1. Bahia-Oliveira LM, Jones JL, Azevedo-Silva J, Alves CC, Oréfice F, Addiss DG Highly endemic, waterborne toxoplasmosis in north Rio de Janeiro state, Brazil. Emerg Infect Dis. 2003;9:55-62.

2. Becker BJ. Toxoplasmic encephalitis in South Africa; report of two cases. S Afr Med J. 1954;28:21-4.

3. Dubey JP, Jones JL. Toxoplasma gondii infection in humans and animals in the United States. Int J Parasitol. 2008;38:1257-78.

4. Denkers EY, Butcher BA. Sabotage and exploitation in macrophages parasitized by intracellular protozoans. Trends Parasitol. 2005;21:35-41.

5. Fasser E. Congenital toxoplasmosis in South Africa; a review and case report. S Afr Med J. 1955;29:684-8.

6. Flegr J, Zitková S, Kodym P, Frynta D. Induction of changes in human behavior by the parasitic protozoan Toxoplasma gondii. Parasitology. 1996;113:49-54.

7. Hari KR, Modi MR, Mochan AH, Modi G. Reduced risk of toxoplasma encephalitis in HIV-infected patients - a prospective study from Gauteng, South Africa. Int J STD AIDS. 2007; 18:555-8.
8. Lin DS, Bowman DD. Toxoplasma gondii: an AIDS enhancing cofactor. Med Hypotheses. 1992;39:140-2.

9. Lindström I, Kaddu-Mulindwa DH, Kironde F, Lindh J. Prevalence of latent and reactivated Toxoplasma gondii parasites in HIV-patients from Uganda. Acta Trop. 2006;100:218-22.

10. Makuwa M, Loemba H, Beuzit Y, Livrozet JM, Belec L. Synthèse intrathécale d'anticorps anti-Toxoplasma gondii au cours de la toxoplasmose cérébrale associée au sida africain. Bull Soc Pathol Exot. 1999;92:95-8.

11. Maschke M, Kastrup O, Esser S, Ross B, Hengge U, Hufnagel A. Incidence and prevalence of neurological disorders associated with HIV since the introduction of highly active antiretroviral therapy (HAART). J Neurol Neurosurg Psychiatry. 2000;69:376-80.

12. Meireles LR, Galisteo AJ Jr, Pompeu E, Andrade HF Jr. Toxoplasma gondii spreading in an urban area evaluated by seroprevalence in free-living cats and dogs. Trop Med Int Health. 2004;9:876-81.

13. Montoya JG, Remington JS. Management of Toxoplasma gondii infection during pregnancy. Clin Infect Dis. 2008;47:554-66.

14. Nabias R, Ngouamizokou A, Migot-Nabias F, Mbou-Moutsimbi RA, Lansoud-Soukate J. Enquête sérologique sur la toxoplasmose chez les consultants du centre de P.M.I de Franceville (Gabon). Bull Soc Pathol Exot. 1998;91:318-20.

15. Passos LN, Araújo Filho OF, Andrade Junior HF. Toxoplasma encephalitis in AIDS patients in São Paulo during 1988 and 1991. A comparative retrospective analysis. Rev Inst Med Trop Sao Paulo. 2000;42:141-5.

16. Purner MB, Berens RL, Tomavo S, Lecordier L, Cesbron-Delauw MF, Kotzin BL, et al. Stimulation of human T lymphocytes obtained from Toxoplasma gondii-seronegative persons by proteins derived from $T$. gondii. J Infect Dis. 1998;177:746-53.

17. Reithinger R, Kamya MR, Whitty CJ, Dorsey G, Vermund SH. Interaction of malaria and HIV in Africa. BMJ. 2009;338:b2141.

18. Shimelis T, Tebeje M, Tadesse E, Tegbaru B, Terefe A. Sero-prevalence of latent Toxoplasma gondii infection among HIV-infected and HIV-uninfected people in Addis Ababa, Ethiopia: a comparative cross-sectional study. BMC Res Notes. 2009;2:213.

19. Stillwaggon E. Complexity, cofactors, and the failure of AIDS policy in Africa. J Int AIDS Soc. 2009; 12:12.

20. Tenter AM, Heckeroth AR, Weiss LM. Toxoplasma gondii: from animals to humans. Int J Parasitol. 2000;30:1217-58.

21. Weiss LM, Dubey JP. Toxoplasmosis: a history of clinical observations. Int J Parasitol 2009;39:895-901.

22. Zumla A, Savva D, Wheeler RB, Hira SK, Luo NP, Kaleebu P, et al. Toxoplasma serology in Zambian and Ugandan patients infected with the human immunodeficiency virus. Trans R Soc Trop Med Hyg. 1991;85:227-9.

Received: 15 June 2010

Accepted: 17 September 2010 